\title{
The triterpenoid alpha, beta-amyrin prevents the impaired aortic vascular reactivity in high-fat diet-induced obese mice
}

\author{
Flávia Almeida Santos ${ }^{1}$ Karine Maria Martins Bezerra Carvalho ${ }^{1}$. \\ Francisco José Batista-Lima ${ }^{1}$ • Paulo Iury Gomes Nunes ${ }^{1}$ • \\ Ana Flávia Seraine Custódio Viana ${ }^{1}$ - Armenio André de Carvalho Almeida da Silva ${ }^{2}$. \\ Said Gonçalves da Cruz Fonseca ${ }^{3}$ - Mariana Helena Chaves ${ }^{2}$. \\ Vietla Satyanarayana Rao ${ }^{1}$ - Pedro Jorge Caldas Magalhães ${ }^{1}$. \\ Teresinha Silva de Brito ${ }^{1}$
}

Received: 23 February 2017 / Accepted: 5 July 2017 / Published online: 17 July 2017

(C) Springer-Verlag GmbH Germany 2017

\begin{abstract}
To characterize the protective effects of the triterpenoid mixture alpha, beta-amyrin (AMY, $20 \mathrm{mg} / \mathrm{kg}$, during 15 days) on the reactivity of isolated aorta of highfat diet (HFD)-induced obese mice. Male Swiss mice were fed with HFD or normal diet (ND) for 15 weeks. Contractions of thoracic aorta in response to $\mathrm{KCl}$ or phenylephrine (PHE) and relaxation by acetylcholine (ACh) or sodium nitroprusside (SNP) were analyzed. HFD-fed mice developed hyperglycemia, hyperlipidemia, and significant body weight gain, parameters prevented by AMY treatment. Whereas aortic contractility did not differ in response to $\mathrm{KCl}$, contractions induced by PHE $(1 \mu \mathrm{M})$ as well as relaxation induced by ACh $(1-30 \mu \mathrm{M})$ or SNP $(1 \mathrm{nM}-0.1 \mathrm{mM})$ on PHE-contracted aorta were decreased $(p<0.05)$ in tissues of HFD compared to ND mice, phenomenon significantly $(p<0.05)$ diminished in HFD mice treated with AMY. The relaxant actions of ACh and SNP were inhibited $(p<0.05)$ by tetraethylammonium (TEA, $5 \mathrm{mM}$ ), apamin $(0.1 \mu \mathrm{M})$, and 4-aminopyridine (4-AP; $3 \mathrm{mM}$ ) in aortae from ND group, but not from HFD. Treatment of HFD mice with AMY rescued the inhibitory effect of TEA $(p<0.05)$ on vasorelaxant
\end{abstract}

Flávia Almeida Santos

fasufc@gmail.com

1 Department of Physiology and Pharmacology, Faculty of Medicine, Federal University of Ceará, Fortaleza, Ceará 60430-270, Brazil

2 Department of Organic Chemistry, Federal University of Piauí, Teresina, Piauí, Brazil

3 Faculty of Pharmacy, Odontology and Nursing, Federal University of Ceará, Fortaleza, Ceará, Brazil actions of ACh and SNP. 1H-[1,2,4]oxadiazolo[4,3a]quinoxalin-1-one (ODQ) inhibited similarly the relaxant effects of SNP in all groups. 8-Br-cGMP relaxed with similar profile aortae of all groups. By preventing HFDinduced obesity in mice, AMY rescued the blunted contractile response to PHE, and the attenuated vasorelaxation and $\mathrm{K}^{+}$channel activation (opening) induced by $\mathrm{ACh}$ and SNP in isolated aorta.

Keywords Alpha, beta-amyrin $\cdot$ High fat diet $\cdot$ Obesity . Aortic vascular reactivity $\cdot$ Thoracic aortic rings

\begin{tabular}{|c|c|}
\hline \multicolumn{2}{|c|}{ Abbreviations } \\
\hline Ach & Acetylcholine \\
\hline 4-AP & 4-aminopyridine \\
\hline AMY & Alpha, beta-amyrin \\
\hline ANOVA & Analysis of variance \\
\hline $\mathrm{BKCa}$ & $\begin{array}{l}\text { Large-conductance } \mathrm{Ca}^{2+} \text {-activated } \\
\text { potassium channel }\end{array}$ \\
\hline DMEM & Dulbecco's modified Eagle's medium \\
\hline DMSO & Dimethyl sulfoxide \\
\hline EDTA & Ethylenediaminetetraacetic acid \\
\hline ELISA & Enzyme-linked immunosorbent assay \\
\hline FBS & Fetal bovine serum \\
\hline GLIB & Glibenclamide \\
\hline HFD & High-fat diet \\
\hline $\mathrm{K}_{\mathrm{ATP}}$ & ATP-sensitive potassium channel \\
\hline Kv & Voltage-dependent potassium channel \\
\hline MKHS & Modified Krebs-Henseleit solution \\
\hline ND & Normal diet \\
\hline NO & Nitric oxide \\
\hline ODQ & $1 \mathrm{H}$-[1,2,4]oxadiazolo[4,3-a]quinoxalin-1-one \\
\hline
\end{tabular}




$\begin{array}{ll}\text { PHE } & \text { Phenylephrine } \\ \text { PSS } & \text { Physiological salt solution } \\ \text { SD } & \text { Standard deviation } \\ \text { SEM } & \text { Standard error of mean } \\ \text { SK } & \begin{array}{l}\text { Small conductance } \mathrm{Ca}^{2+} \text {-activated } \\ \text { potassium channel }\end{array} \\ & \text { Sodium nitroprusside } \\ \text { TEP } & \text { Tetraethylammonium }\end{array}$

\section{Introduction}

Past studies have suggested that a high-fat diet (HFD) is likely involved in the development of vascular disease caused by obesity (Barton and Furrer 2003; Mundy et al. 2007; Costa et al. 2011; Nascimento et al. 2011). Obesity increases the risk of the development of metabolic and cardiovascular diseases due to a disruption in adipose tissue function, leading to a chronic inflammatory state (Van de Voorde et al. 2014). Proinflammatory cytokines locally produced by perivascular fat and the dysregulation of the endocrine and paracrine actions of adipocyte-derived factors such as leptin, adiponectin, and resistin (Kougias et al. 2005; Liu et al. 2010) contribute to endothelial dysfunction, smooth muscle cell dysfunction, and the pathogenesis of vascular disease in obese individuals (Iantorno et al. 2014). Studies have shown an association between low adiponectin and high leptin levels with obesityrelated metabolic disturbances and the incidence of coronary heart disease (Shanker et al. 2012). Therefore, new compounds that could ameliorate visceral adiposity and vascular alterations are desired to improve the quality of treatment for obesity.

Presently, there is a growing interest in and awareness of the roles of herbal medicines in the treatment and prevention of cardiovascular diseases (Walden and Tomlinson 2011). Herbal compounds rich in triterpenoids are well-known regulators of glucose and lipid metabolism and have beneficial effects on metabolic disorders and the prevention of obesity (Sudhahar et al. 2006; de Melo et al. 2009; de Melo et al. 2010; Rao et al. 2011; Castellano et al. 2013; Cai et al. 2014). Studies have demonstrated the potential of triterpenoids from olive oil as a therapeutic strategy in preventing vascular injury and the progression of cardiovascular diseases (Xiang et al. 2012). We have previously reported on the anti-obesity and hypolipidemic properties of the resin from Protium heptaphyllum and its major triterpenoid constituents, alphaand beta-amyrin (AMY), in mice subjected to an HFD for 15 weeks (Carvalho et al. 2015; Carvalho et al. 2017). We have previously demonstrated the anti-obesity and pro-weight-loss potential of AMY, largely attributed to its modulatory effects on various hormonal and enzymatic secretions related to fat and carbohydrate metabolism and to the regulation of obesityassociated inflammation (Carvalho et al. 2015); however, whether AMY can offer protective effects against the influences of obesity on vascular reactivity has not been established. It is well known that endothelial dysfunction plays an essential role in the initiation of the cascade of events leading to cardiovascular risk factors (Reriani et al. 2010), and a number of pathological conditions are associated with endothelial dysfunction, including diabetes, dyslipidemia, and obesity (Boger et al. 1997; Virdis et al. 2013; Wilk et al. 2013). Porto et al. (2010) reported that maternal diabetes produced alterations in $\mathrm{K}^{+}$channel activity on the endothelium-dependent aortic relaxation induced by acetylcholine in adult offspring rats. In the present study, we aimed to analyze the contractile and relaxant vascular responses of thoracic aortas collected from mice fed with a normal diet or an HFD and treated or not with AMY for 15 weeks, with an emphasis on the involvement of the guanylate cyclase- $\mathrm{K}^{+}$channel pathway in the vascular responses.

\section{Materials and methods}

\section{Drugs and chemicals}

The following compounds were used in the experiments: phenylephrine hydrochloride (PHE), acetylcholine chloride (ACh), tetraethylammonium chloride (TEA), glibenclamide (GLIB), 4-aminopyridine (4-AP), 1H-[1,2,4]oxadiazolo[4,3a]quinoxalin-1-one (ODQ), 8-Br-cGMP, apamin (Sigma Chemical Co., St. Louis, Missouri, USA), sodium pentobarbital (Fontoveter, Brazil), and sodium nitroprusside (SNP; Merck \& Co., Inc., Rahway, NY, USA). Glibenclamide and ODQ were prepared in DMSO with a final concentration of 0.04 and $0.1 \%$, respectively, in an organ bath. Apamin was prepared in acetic acid with a final concentration of $0.02 \%$ in an organ bath. Further dilutions of all stock solutions were prepared in distilled water. In the present study, a triterpenoid mixture composed of alpha- and beta-amyrin (63:37, AMY) was isolated from the resin of $P$. heptaphyllum per the methods described previously (Olea and Roque 1990; Mahato and Kundu 1994; Vieira-Junior et al. 2005). For experiments, AMY was suspended initially in 2\% Tween $80(v / v)$ and then further diluted in distilled water. Salts and reagents used were of analytical grade.

\section{Animals and the HFD experimental protocol}

Male Swiss mice aged 6 weeks and weighing 20-25 g obtained from the Central Animal House of the Federal University of Ceará were used. They were housed in a controlled environment $\left(24 \pm 2{ }^{\circ} \mathrm{C}, 55 \pm 5 \%\right.$ relative humidity, $12 \mathrm{~h}$ light/dark cycle), and food (chow) and water were provided ad libitum. All experiments involving mice were approved by the Institutional Animal Care and Use Committee of the Federal University of 
Ceará (Protocol Number 17/2011) in accordance with the Guidelines of National Institutes of Health (Bethesda, MD).

The standardized HFD used for the study (Estadella et al. 2004) was comprised of the following hypercaloric constituents: $15 \mathrm{~g}$ laboratory animal chow, $10 \mathrm{~g}$ roasted ground nut, $10 \mathrm{~g}$ milk chocolate, and $5 \mathrm{~g}$ maizen biscuits. These ingredients were ground and prepared in the form of pellets containing $20 \%$ protein, $48 \%$ carbohydrate, $20 \%$ lipids, $4 \%$ cellulose, $5 \%$ vitamins and minerals, and $3 \%$ moisture by weight. This diet has the net energy content of $21.40 \mathrm{~kJ} / \mathrm{g}$. To avoid the autoxidation of the fat components, the food was stored at $\sim 24{ }^{\circ} \mathrm{C}$. Laboratory pellet chow was used as the control diet (Nuvilab), which consisted of $19 \%$ protein, $56 \%$ carbohydrate, $3.5 \%$ lipids, $4.5 \%$ cellulose, $5.0 \%$ vitamins and minerals, and $12 \%$ humidity with a net energy content of $17.03 \mathrm{~kJ} / \mathrm{g}$.

The animals were randomly divided into three groups of eight ( $n=8)$, matched for body weight, after 1 week of being fed the laboratory pellet chow. The normal control group continued to be fed with the laboratory pellet chow ad libitum and was designated ND. The remaining mice consumed a high-fat diet without (HFD control) or with AMY at $20 \mathrm{mg} / \mathrm{kg}$ (HFD + AMY 20) for 15 weeks. Since the effect of the $20 \mathrm{mg} / \mathrm{kg}$ AMY dose was more consistent than that of the $10 \mathrm{mg} / \mathrm{kg}$ dose, the $20 \mathrm{mg} / \mathrm{kg}$ dose was chosen for the current study. HFD-fed controls received the same vehicle in which AMY was suspended. AMY- or vehicle-containing water was changed twice per week, and weekly consumption of water $(\mathrm{mL} /$ week) was noted.

The body weight of each mouse was measured weekly, as were the consumption of food $(\mathrm{g})$ and water $(\mathrm{mL})$. At the end of this period, animals were starved for $6 \mathrm{~h}$, and blood was taken by venous puncture under light anesthesia with diethyl ether. Blood samples were centrifuged at $2000 \times g$ for $10 \mathrm{~min}$ at $4{ }^{\circ} \mathrm{C}$. The plasma was then removed and used within a few hours or immediately frozen at $-70^{\circ} \mathrm{C}$ until analysis. All mice were sacrificed by cervical dislocation. The thoracic aorta from each mouse was gently excised and equilibrated in physiological salt solution (PSS) buffer ( $\mathrm{pH} \mathrm{7.4)}$ at $37^{\circ} \mathrm{C}$. The abdominal adipose tissues (epididymal and parametrial) were removed, weighed, and expressed in $\mathrm{mg}$ per $10 \mathrm{~g}$ body weight.

Plasma glucose (cat. no. 133), triglycerides (cat. no. 87) and total cholesterol (cat. no. 76) were determined using specific assay kits (Labtest, Minas Gerais, Brazil). Plasma insulin (cat. no. EZRMI-13K), adiponectin (cat. no. EZMADP-60K; Millipore, Billerica, MA, USA), and leptin (cat. no. MOB00; R\&D Systems, Minneapolis, MN, USA) were measured using enzyme-linked immunosorbent assay (ELISA).

\section{Vascular reactivity studies}

The excised thoracic aortas were placed in Petri dishes containing modified Krebs-Henseleit solution (MKHS) at room temperature (MKHS in mM $118.0 \mathrm{NaCl}, 4.7 \mathrm{KCl}, 2.5 \mathrm{CaCl}_{2}$, $1.18 \mathrm{MgSO}_{4} 7 \mathrm{H}_{2} \mathrm{O}, 1.18 \mathrm{KH}_{2} \mathrm{PO}_{4}, 25.0 \mathrm{NaHCO}_{3}, 11.0 \mathrm{glu}-$ cose [pH 7.4]). After cleaning the loose connective tissue, each aorta was cut transversally into cylindrical ring-like segments (3-4 $\mathrm{mm}$ each) and attached to steel wire triangular pieces, which were suspended in 5-ml organ baths containing the perfusion medium (continuously aerated at $37^{\circ} \mathrm{C}$ with $5 \%$ $\mathrm{CO}_{2}$ in $\mathrm{O}_{2}$ ). Endothelium-containing preparations were stretched with a passive tension of $1 \mathrm{~g}$, and the tension was recorded using an isometric force transducer (ML870B60/C$\mathrm{V}$, AD Instruments, Australia) connected to a data acquisition system (PowerLab 8/30, AD Instruments). In all experiments, to evaluate the viability of tissues after an equilibration period of $60 \mathrm{~min}$, control contractions were induced by adding a submaximal concentration $(60 \mathrm{mM})$ of $\mathrm{KCl}$ to the bath. Aortic preparations were considered functionally equilibrated when two successive KCl-induced contractions had a similar magnitude. Tissues without reproducible contractions were discarded.

Concentration-response curves were constructed in response to the contractile agents $\mathrm{KCl}(10-120 \mathrm{mM})$ or phenylephrine (PHE, 0.001-10 $\mu \mathrm{M}$ ). During the steady state of a PHEinduced contraction $(1 \mu \mathrm{M})$, the relaxant effects of acetylcholine $(\mathrm{ACh}, 1-30 \mu \mathrm{M})$ or sodium nitroprusside (SNP, 1$1000 \mathrm{nM}$ ) were recorded. The relaxation responses to $\mathrm{ACh}$ and SNP were expressed as percentages of the maximal relaxant response. Further, to characterize the mechanisms involved in the relaxant effects of ACh and SNP on PHE-induced contractions, the aortic rings were incubated with glibenclamide (GLIB, $10 \mu \mathrm{M})$, an ATP-sensitive potassium channel $\left(\mathrm{K}_{\mathrm{ATP}}\right)$ blocker; tetraethylammonium (TEA, $5 \mathrm{mM}$ ), a largeconductance $\mathrm{Ca}^{2+}$-activated potassium channel $\left(\mathrm{BK}_{\mathrm{Ca}}\right)$ blocker; apamin $(0.1 \mu \mathrm{M})$, a small conductance $\mathrm{Ca}^{2+}$-activated potassium channel (SK) blocker; 4-aminopyridine (4-AP, $3 \mathrm{mM})$, a voltage-dependent potassium channel $\left(\mathrm{K}_{\mathrm{V}}\right)$ blocker; or with a soluble guanylate cyclase inhibitor, 1H-[1,2,4] oxadiazolo[4,3-a]quinoxalin-1-one (ODQ, $10 \mu \mathrm{M}$ ). Each inhibitor was added to the bath for $10 \mathrm{~min}$ before PHE $(1 \mu \mathrm{M})$. The concentrations of the inhibitors used in the present study were usually as recommended in the literature.

\section{Statistical analyses}

All data are reported as the mean \pm standard deviation (SD) or standard error of mean (SEM), with $n$ indicating the number of experiments. The $\mathrm{EC}_{50}$ (i.e., the concentration of a relaxant compound at which $50 \%$ of a contractile response was inhibited) values were calculated by interpolation from semilogarithmic plots and expressed as the geometric mean $(95 \%$ confidence interval). Data were analyzed using a one- or twoway analysis of variance (ANOVA) followed by a HolmSidak multiple comparison test. Differences were considered statistically significant at $p<0.05$. 


\section{Results}

\section{Effects of AMY treatment on obesity-related parameters in HFD mice}

There was no significant difference in the initial body weights among the four groups of mice. At the end of 15 weeks, the values of final body weight and net food consumption were significantly higher $(p<0.05)$ in HFD group $(55.57 \mathrm{~g}$ and $48.35 \mathrm{~g}$, respectively) than in ND group (41.33 $\mathrm{g}$ and $33.36 \mathrm{~g}$, respectively; Table 1). Compared to the ND group, the HFD mice revealed a $34.4 \%$ weight gain. Treatment with AMY $(20 \mathrm{mg} / \mathrm{kg})$ reduced the weight gain to $12.3 \%$ in the HFD + AMY 20 group, which was significantly lower in comparison with the HFD group $(p<0.05)$. There was a significant increase in the values of food consumption in the HFD group (44.9\%) but not in the groups treated with AMY when compared to the ND group. AMY treatment, while it significantly decreased the HFD-induced increases in the levels of glucose, insulin, leptin, cholesterol, and triglycerides to the extent of $28,72,92,27$, and $41 \%$, respectively, it increased the HFD-induced decreases in the level of adiponectin by $24 \%$.

\section{Vascular reactivity in mice fed a HFD and the effects of AMY treatment}

Concentration-response curves constructed on mice aortic rings in response to $\mathrm{KCl}(10-120 \mathrm{mM})$ or PHE (0.001$10 \mu \mathrm{M})$ are shown in Fig. 1 and Table 2. While the contractile response to $\mathrm{KCl}$ (Fig. 1a) did not reveal a significant difference between groups, the magnitude of the maximal contraction induced by PHE (Fig. 1b) was significantly lower in the aortic rings of HFD mice in comparison with the ND group (at $10 \mu \mathrm{M}$ PHE: HFD $=0.44 \pm 0.04 \mathrm{~g}[n=17]$; $\mathrm{ND}=0.57 \pm 0.06 \mathrm{~g}[n=12] ; p<0.05)$. In contrast, the aortic rings of mice treated with AMY $(20 \mathrm{mg} / \mathrm{kg})$ showed no significant difference $(p>0.05)$ in their maximal values in comparison with the ND group $(0.55 \pm 0.02 \mathrm{~g}[n=9])$. Figure 2 shows the vasorelaxant responses to increasing concentrations of ACh (1-30 $\mu \mathrm{M}$; Fig. 2a) or SNP (1-1000 nM; Fig. 2b, c) applied during the steady state of a contraction previously induced by PHE ( $1 \mu \mathrm{M}$; Fig. $2 \mathrm{a}, \mathrm{b})$ or $\mathrm{KCl}(60 \mathrm{mM}$; Fig. $2 \mathrm{c})$. In the aortic rings of HFD mice, ACh-induced relaxation $(22.9 \pm 4.7 \%[n=8])$ was significantly lower than in tissues of the ND group $(50.1 \pm 6.4 \%[n=11]$; Fig. $2 \mathrm{a})$. The relaxant responses to SNP (at 10 and $100 \mathrm{nM}$ ) in aortic rings precontracted by PHE (1 $\mu \mathrm{M})$ were found to be significantly $(p<0.05)$ attenuated in the HFD tissues $(23.9 \pm 3.0$ and $57.4 \pm 6.4 \%$, respectively $[n=4])$ compared to the ND group $(47.8 \pm 5.6$ and $77.3 \pm 1.5 \%$, respectively, for SNP 10 and $100 \mathrm{nM}[n=7]$; Fig. 2b). When the contractile stimulus was $60 \mathrm{mM} \mathrm{KCl}$ (Fig. 2c), the maximal relaxant response induced by $1000 \mathrm{nM}$ SNP was significantly decreased in rings of the ND group $(47.1 \pm 9.0 \%[n=7])$, but no significant difference was observed in comparison with responses in the HFD group $(35.9 \pm 3.7 \%[n=6])$ or the HFD + AMY 20 group $(43.4 \pm 7.4 \%[n=9] ; p>0.05)$.

In the aortic rings of mice treated with AMY $(20 \mathrm{mg} / \mathrm{kg})$ and subjected to the HFD, the vasorelaxant effects caused by ACh (at $30 \mu \mathrm{M}=42.3 \pm 7.0 \%[n=6]$ ) were significantly higher in comparison with the tissues of animals subjected only to the HFD (Fig. 2a). The vasorelaxant effects of 10 and $100 \mathrm{nM}$ SNP were similarly increased $(50.0 \pm 3.7$ and $85.2 \pm 1.8 \%$, respectively $[n=5])$ in the HFD + AMY 20 group than in the group subjected only to the HFD (Fig. 2b).
Table 1 Effects of alpha, betaamyrin (AMY) treatment on HFD-induced obesity-related parameters in mice

\begin{tabular}{lccc}
\hline Group & ND & HFD & HFD + AMY 20 mg/kg \\
\hline Initial body weight $(\mathrm{g})$ & $22.10 \pm 1.52$ & $21.58 \pm 2.64$ & $22.43 \pm 1.39$ \\
Final body weight $(\mathrm{g})$ & $41.33 \pm 3.24$ & $55.57 \pm 7.45^{*}$ & $46.43 \pm 2.64^{\#}$ \\
Net food intake $(\mathrm{g} / \mathrm{week})$ & $33.36 \pm 6.48$ & $48.35 \pm 11.39^{*}$ & $27.81 \pm 4.86^{\#}$ \\
Net water intake $(\mathrm{mL} / \mathrm{week})$ & $50.31 \pm 3.28$ & $48.40 \pm 5.08$ & $50.60 \pm 5.13$ \\
Abdominal fat $(\mathrm{mg} / \mathrm{l0} \mathrm{g})$ & $174.50 \pm 56.69$ & $732.80 \pm 238.40^{*}$ & $333.10 \pm 117.10^{\#}$ \\
Glucose $(\mathrm{mg} / \mathrm{dL})$ & $118.80 \pm 23.80$ & $212.20 \pm 44.31^{*}$ & $152.60 \pm 40.19^{\#}$ \\
Insulin $(\mathrm{ng} / \mathrm{mL})$ & $1.385 \pm 0.676$ & $5.544 \pm 3.256^{*}$ & $1.520 \pm 0.835^{\#}$ \\
Leptin $(\mathrm{pg} / \mathrm{mL})$ & $156.4 \pm 84.0$ & $1514.0 \pm 1194.0^{*}$ & $113.10 \pm 76.66^{\#}$ \\
Adiponectin $(\mathrm{ng} / \mathrm{mL})$ & $7.650 \pm 2.059$ & $4.763 \pm 1.165^{*}$ & $6.289 \pm 1.048^{\#}$ \\
Total cholesterol $(\mathrm{mg} / \mathrm{dL})$ & $124.90 \pm 11.22$ & $214.20 \pm 30.22^{*}$ & $156.20 \pm 23.19^{\#}$ \\
Triglycerides $(\mathrm{mg} / \mathrm{dL})$ & $106.40 \pm 34.69$ & $197.10 \pm 58.17^{*}$ & $115.60 \pm 19.94^{\#}$ \\
\hline
\end{tabular}

Values are means $\pm \mathrm{SD}$

$N D$ normal diet, $H F D$ high-fat diet, $A M Y$ alpha, beta-amyrin; $* p<0.05$ vs mice fed ND, \#p $<0.05$ vs mice fed HFD 
a

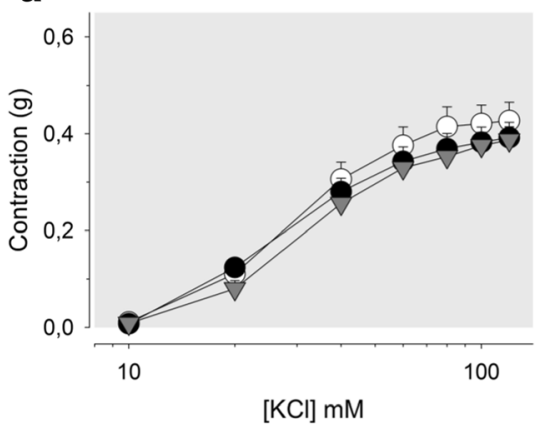

Fig. 1 Concentration-effect curves of mice aortic rings in response to $\mathrm{KCl}$ and phenylephrine. Contractions were obtained by the addition of increasing concentrations of $\mathrm{KCl}(10-120 \mathrm{mM}$; a) or phenylephrine (PHE; $0.001-10 \mu \mathrm{M}$; b) in aortic rings of mice subjected to normal diet $[\mathrm{ND}$, white circle $(\mathrm{KCl}, n=12$; PHE, $n=12)]$, high-fat diet [HFD, black circle (KCl, $n=17$; PHE, $n=17)$ ] or HFD with alpha, beta amyrin [AMY;

\section{Involvement of the guanylate cyclase- $\mathrm{K}^{+}$channel pathway in the vascular responses to acetylcholine in mouse aortic rings contracted with phenylephrine}

Recruitment of the guanylate cyclase- $\mathrm{K}^{+}$channel pathway in the vasorelaxant response to ACh $(1-30 \mu \mathrm{M})$ in PHE $(1 \mu \mathrm{M})$ b

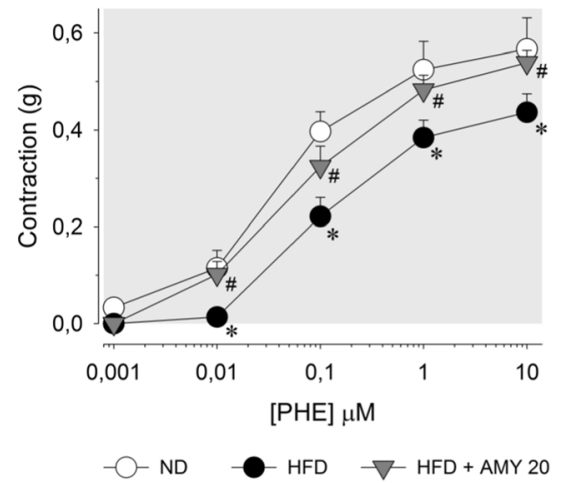

$20 \mathrm{mg} / \mathrm{kg}$; inverted triangle ( $\mathrm{KCl}, n=13$; PHE, $n=9)$ ]. Vasoconstriction is expressed in $\mathrm{g}$. Values are mean and vertical bars indicate S.E.M. $* p<0.05$ in comparison with the same concentration in ND group. $\# p<0.05$ comparing the same concentration in relation to HFD group (two-way ANOVA followed by Holm-Sidak test)

pre-contracted aortic rings was examined in the aortic rings of mice receiving the ND, HFD, and HFD + AMY $20 \mathrm{mg} / \mathrm{kg}$. As shown in Fig. 3, the vasorelaxant effect caused by ACh was abolished in preparations treated with the guanylate cyclase inhibitor $1 H$-[1,2,4]oxadiazolo[4,3-a]quinoxalin-1-one (ODQ) in all groups (Fig. 3a-c).

Table 2 Values of $\mathrm{pD}_{2}$ and $\mathrm{E}_{\max }$ for the vasoactive effects recorded on aortic rings from mice fed with ND, HFD, or HFD + AMY 20 mg/kg

\begin{tabular}{|c|c|c|c|c|}
\hline Contractile stimulus & Group & $\mathrm{pD}_{2}$ & $\mathrm{E}_{\max }(\mathrm{g})$ & Number \\
\hline \multirow[t]{3}{*}{$\mathrm{KCl}$} & ND & $1.53(1.47-1.59)$ & $0.42 \pm 0.04$ & 12 \\
\hline & HFD & $1.57(1.51-1.64)$ & $0.39 \pm 0.03$ & 17 \\
\hline & $\mathrm{HFD}+\mathrm{AMY} 20 \mathrm{mg} / \mathrm{kg}$ & $1.51(1.44-1.58)$ & $0.39 \pm 0.02$ & 13 \\
\hline \multirow[t]{3}{*}{ PHE } & ND & $7.46(7.23-7.68)$ & $0.57 \pm 0.06$ & 12 \\
\hline & HFD & $6.95(6.80-7.10)^{*}$ & $0.44 \pm 0.04 *$ & 17 \\
\hline & $\mathrm{HFD}+\mathrm{AMY} 20 \mathrm{mg} / \mathrm{kg}$ & $7.20(6.89-7.51)$ & $0.55 \pm 0.02$ & 9 \\
\hline Relaxant stimulus & Group & $\mathrm{pD}_{2}$ & $\mathrm{E}_{\max }(\%)$ & $n$ \\
\hline \multirow[t]{3}{*}{ ACh (PHE) } & ND & - & $50.13 \pm 6.45$ & 11 \\
\hline & HFD & - & $22.89 \pm 4.73 *$ & 8 \\
\hline & $\mathrm{HFD}+\mathrm{AMY} 20 \mathrm{mg} / \mathrm{kg}$ & - & $42.30 \pm 7.00$ & 6 \\
\hline \multirow[t]{3}{*}{ SNP (PHE) } & ND & $7.92(7.60-8.23)$ & $100.0 \pm 0.00$ & 7 \\
\hline & HFD & $7.23(6.78-7.67)^{*}$ & $100.0 \pm 0.00$ & 4 \\
\hline & $\mathrm{HFD}+\mathrm{AMY} 20 \mathrm{mg} / \mathrm{kg}$ & $8.08(7.79-8.37)$ & $100.0 \pm 0.00$ & 5 \\
\hline \multirow[t]{3}{*}{$\mathrm{SNP}(\mathrm{KCl})$} & ND & - & $47.12 \pm 9.05$ & 7 \\
\hline & HFD & - & $33.20 \pm 4.11$ & 6 \\
\hline & $\mathrm{HFD}+\mathrm{AMY} 20 \mathrm{mg} / \mathrm{kg}$ & - & $43.43 \pm 7.44$ & 9 \\
\hline \multirow[t]{3}{*}{ 8-Br-cGMP (PHE) } & ND & $4.65(4.46-4.67)$ & $97.17 \pm 2.27$ & 7 \\
\hline & HFD & $4.60(4.44-4.75)$ & $95.42 \pm 2.54$ & 7 \\
\hline & $\mathrm{HFD}+\mathrm{AMY} 20 \mathrm{mg} / \mathrm{kg}$ & $4.54(4.44-4.64)$ & $94.56 \pm 2.82$ & 6 \\
\hline
\end{tabular}

$\mathrm{pD}_{2}$ values are the negative logarithm of the $\mathrm{EC}_{50}$ shown as the geometric mean with $95 \%$ confidence intervals in parentheses. Relaxant stimulus was applied with acetylcholine (ACh), sodium nitroprusside (SNP), or 8-Br-cGMP added on the steady state of a contraction induced by PHE or KCl as indicated

- Not applicable, $N D$ normal diet, $H F D$ high-fat diet, $A M Y$ alpha, beta-amyrin, $E_{\max }(g)$ maximal contraction induced by phenylephrine (PHE) or KCl, expressed in g, $E_{\text {max }}(\%)$ maximal relaxation induced by ACh, SNP, or 8-Br-cGMP expressed as \% of the contraction induced by $\mathrm{PHE}$ or $\mathrm{KCl}$

$* p<0.05$ vs ND group 


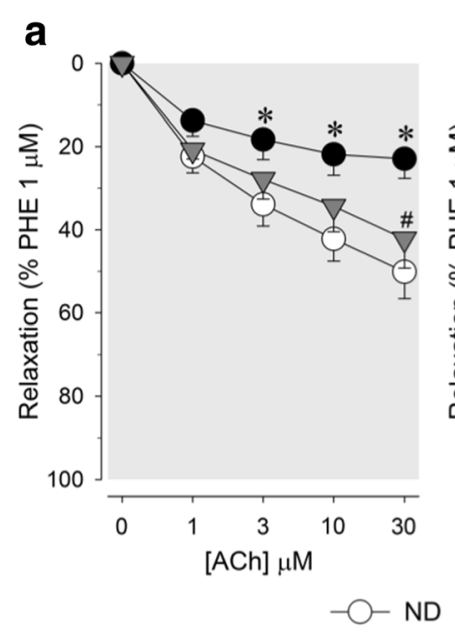

\section{b}

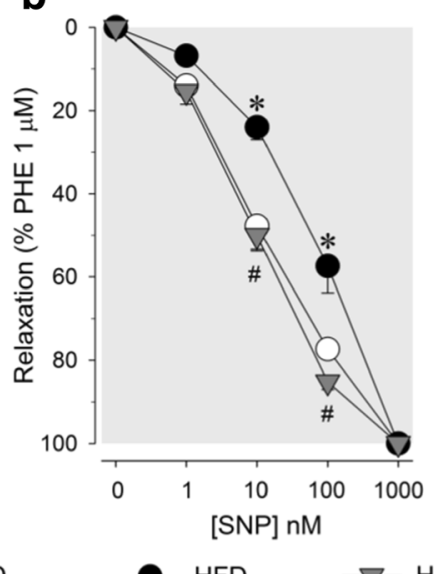

C

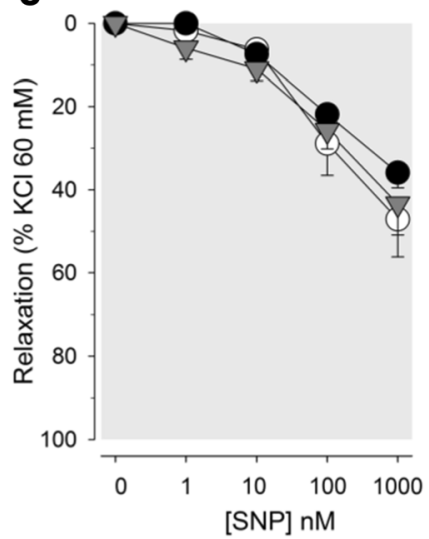

HFD + AMY 20

Fig. 2 Vasorelaxant responses to acetylcholine and sodium nitroprusside in mice aortic rings pre-contracted with phenylephrine or KCl. Aortic rings of mice subjected to normal diet (ND, white circle), high-fat diet (HFD, black circle) or HFD with alpha, beta amyrin (AMY; $20 \mathrm{mg} / \mathrm{kg}$; inverted triangle) were initially contracted with phenylephrine (PHE, $1 \mu \mathrm{M}$; a, b) or $\mathrm{KCl}(60 \mathrm{mM}$; c). On the steady-state contraction, acetylcholine [ACh, 1-30 $\mu \mathrm{M}$; a (ND, $n=11 ; \mathrm{HFD}, n=8$; HFD + AMY20, $n=6)$ ] or sodium nitroprusside [SNP, $1-1000 \mathrm{nM}$; b (ND, $n=7$; HFD, $n=4$; HFD + AMY20, $n=5)$ and $\mathbf{c}(\mathrm{ND}, n=7$; HFD, $n=6$; HFD + AMY20, $n=9$ )] were added to produce vasorelaxant responses, which were expressed as \% of the control contraction induced by PHE (a and $\mathbf{v}$ ) or $\mathrm{KCl}(60 \mathrm{mM}, \mathbf{c})$ before the addition of ACh or SNP. Values are mean \pm SEM. $* p<0.05$ in comparison with the same concentration in ND group. $\# p<0.05$ comparing the same concentration in relation to HFD group (two-way ANOVA followed by Holm-Sidak test)
In contrast, pharmacological blockade of $\mathrm{K}^{+}$channels with tetraethylammonium (TEA, $5 \mathrm{mM})$, apamin $(0.1 \mu \mathrm{M})$, or 4aminopyridine (4-AP, $3 \mathrm{mM})$ significantly $(p<0.05)$ reduced the vasorelaxant response to ACh in the ND group (at $30 \mu \mathrm{M}$ from $50.1 \pm 6.4$ to $15.8 \pm 4.1 \%[n=8], 21.09 \pm 5.8 \%[n=5]$, and $21.9 \pm 3.9 \%$ [ $n=5]$, respectively; Fig. 3a). Glibenclamide (GLIB, $10 \mu \mathrm{M}$ ) did not interfere with the cholinergic relaxation in the ND group. Glibenclamide was similarly inert
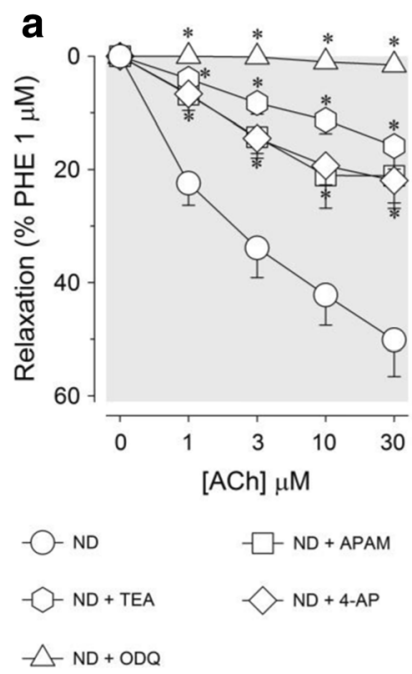
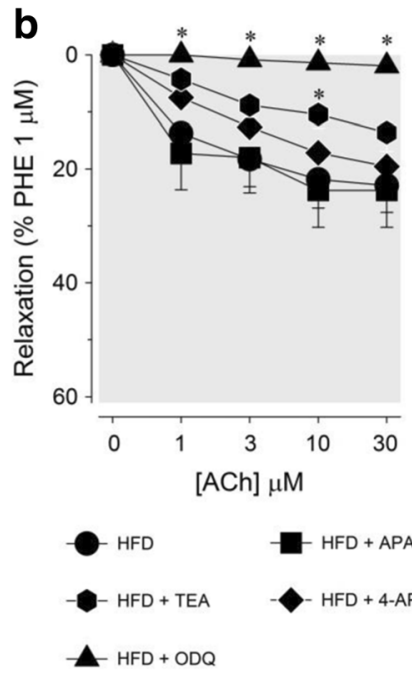

Fig. 3 Involvement of guanylate cyclase- $\mathrm{K}^{+}$channel pathways in the vasorelaxant responses to acetylcholine in mice aortic rings precontracted with phenylephrine. Aortic rings of mice subjected to normal diet (ND, white symbols), high-fat diet (HFD, black symbols), or HFD with alpha, beta-amyrin (AMY; $20 \mathrm{mg} / \mathrm{kg}$; gray symbols) were initially contracted with phenylephrine (PHE, $1 \mu \mathrm{M})$. Preparations were maintained in the absence (ND, $n=11$; HFD, $n=8$; HFD + AMY20, $n=7$ ) or in the presence of the $\mathrm{K}^{+}$channel blockers (apamin [APAM, $0.1 \mu \mathrm{M}$; squares; $\mathrm{ND}, n=5$; HFD, $n=5 ; \mathrm{HFD}+\mathrm{AMY} 20, n=6]$, tetraethylammonium [TEA, $5 \mathrm{mM}$; hexagons; ND, $n=8$; HFD, $n=8$;
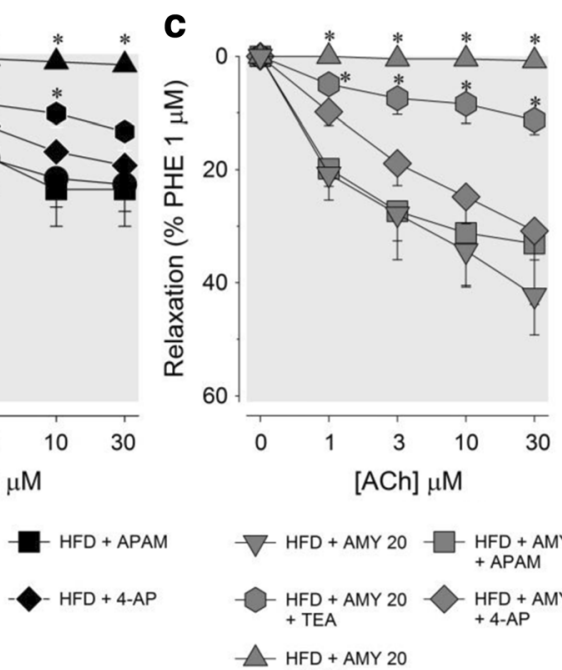

HFD + AMY20, $n=6$ ], or 4-aminopyridine [4-AP, $3 \mathrm{mM}$; diamonds; $\mathrm{ND}, n=8$; HFD, $n=5$; HFD + AMY20, $n=5]$ ), or the guanylate cyclase inhibitor $1 \mathrm{H}-[1,2,4]$ oxadiazolo[4,3-a]quinoxalin-1-one (ODQ, $10 \mu \mathrm{M}$; up triangles; ND, $n=6$; HFD, $n=6$; HFD + AMY20, $n=4)$. On the steady-state contraction, acetylcholine (ACh, 1-30 $\mu \mathrm{M}$ ) was added to produce vasorelaxant responses, which were expressed as \% of the control contraction induced by PHE before ACh addition. Values are mean \pm SEM. $* p<0.05$ in comparison with the same concentration in ND group (two-way ANOVA followed by Holm-Sidak test) 
against $\mathrm{ACh}$ in the aortic rings of mice subjected to the HFD and the HFD + AMY 20 (data not shown). In the aortic rings of HFD mice (Fig. 3b), the $\mathrm{K}^{+}$-channel blockers TEA, apamin, and 4-AP revealed a tendency to inhibit the relaxant action of $\mathrm{ACh}$, but their values did not achieve statistical significance in comparison with the HFD non-treated preparations $(p>0.05)$. In the HFD mice treated with AMY (20 mg/kg; Fig. 3c), the relaxation induced by ACh almost attained the level observed in the ND mice and was significantly reduced $(p<0.05$ ) by TEA (at $30 \mu \mathrm{M}$ ACh, the effect was reduced to $11.3 \pm 2.5 \%[n=8]$ vs. $42.3 \pm 7.0 \%[n=5]$ in the HFD + AMY 20 preparations without TEA) but not by $4-$ AP or apamin.

\section{Involvement of the guanylate cyclase- $\mathrm{K}^{+}$channel pathway in the vascular response to sodium nitroprusside in aortic rings contracted with phenylephrine}

Figure 4 represents the vasorelaxant responses of mice aortic rings initially contracted with PHE $(1 \mu \mathrm{M})$ and subjected to increasing concentrations of sodium nitroprusside (SNP, 1$1000 \mathrm{nM})$ in the absence or in the presence of GLIB $(10 \mu \mathrm{M})$, TEA $(5 \mathrm{mM})$, apamin $(0.1 \mu \mathrm{M}), 4-\mathrm{AP}(3 \mathrm{mM})$, or ODQ $(10 \mu \mathrm{M})$. In the aortic rings of ND mice (Fig. $4 \mathrm{a})$, the relaxing effects of SNP were sensitive to pharmacological blockade of $\mathrm{K}^{+}$channels with TEA, apamin, and 4-AP, but not with GLIB. Values for the relaxant effects of SNP were significantly reduced at 1,10 , and $100 \mathrm{nM}$ and at 10 and $100 \mathrm{nM}$ in preparations treated with TEA and 4-AP, respectively, and at $10 \mathrm{nM}$ in preparations treated with apamin $(p<0.05)$. Such a reduction induced by the presence of these $\mathrm{K}^{+}$-channel blockers was not statistically evident in the aortic rings from the HFD group ( $p>0.05$; Fig. $4 \mathrm{~b}$ ). In the HFD mice treated with AMY (20 mg/kg; Fig. 4c), the relaxant responses induced by 10 and $100 \mathrm{nM}$ SNP were significantly reduced by treatment with TEA $(23.1 \pm 5.0$ and $59.3 \pm 6.2 \%$ in TEA-treated preparations vs. $50.0 \pm 3.7$ and $85.2 \pm 1.8 \%$ in non-treated preparations, respectively; $p<0.05$ ), but not with GLIB or 4-AP. It should be highlighted that the inhibition of guanylate cyclase through treatment with ODQ significantly reduced the relaxant effect of SNP in all groups $(p<0.05)$.

\section{Vasorelaxant response to 8-Br-cGMP in aortic rings pre-contracted with $\mathrm{PHE}$ in mice receiving a ND, HFD, or HFD with AMY}

To evaluate the responsiveness of aortic smooth muscle cells to cGMP, the relaxant response caused by the cell-permeable cGMP analog 8-Br-cGMP $(1-100 \mu \mathrm{M})$ was measured in PHE $(1 \mu \mathrm{M})$-contracted thoracic aortic preparations from mice fed a ND, HFD, or HFD + AMY $20 \mathrm{mg} / \mathrm{kg}$. Figure 5 shows that the vasorelaxant response to 8 -Br-cGMP in the HFD group $\left(\mathrm{pD}_{2}=4.60\right.$ [4.44-4.75]; $\left.n=7\right)$ was not significantly different in comparison with the ND group $\left(\mathrm{pD}_{2}=4.65\right.$ [4.46-4.67];
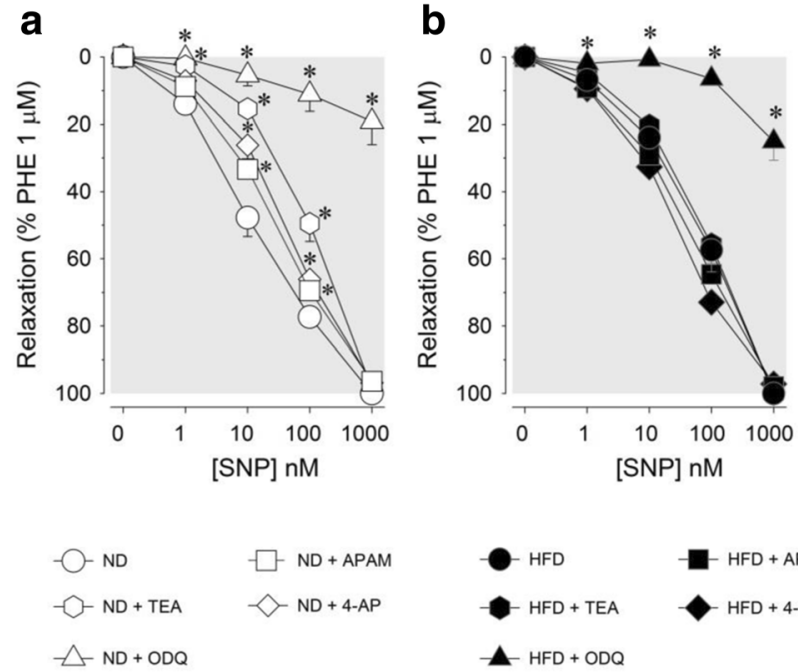

Fig. 4 Involvement of guanylate cyclase- $\mathrm{K}^{+}$channel pathways in the vasorelaxant responses to sodium nitroprusside in mice aortic rings precontracted with phenylephrine. Aortic rings of mice subjected to normal diet (ND, white symbols), high-fat diet (HFD, black symbols), or HFD with alpha, beta amyrin (AMY; $20 \mathrm{mg} / \mathrm{kg}$; gray symbols) were initially contracted with phenylephrine (PHE, $1 \mu \mathrm{M}$ ). Preparations were maintained in the absence (ND, $n=7$; HFD, $n=4$; HFD + AMY20, $n=5$ ) or in the presence of the $\mathrm{K}^{+}$channel blockers (apamin [APAM, $0.1 \mu \mathrm{M}$; squares; ND, $n=10$; HFD, $n=6$; HFD + AMY20, $n=7]$, tetraethylammonium [TEA, $5 \mathrm{mM}$; hexagons; ND, $n=7$; HFD, $n=5$;
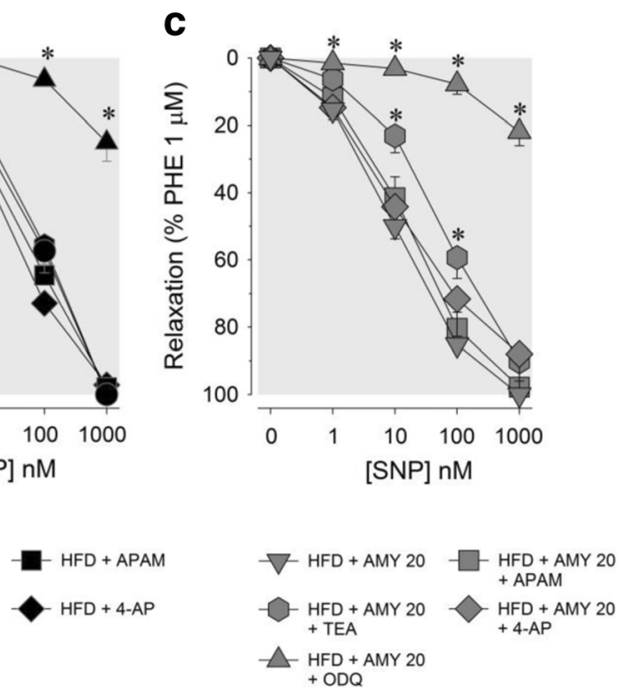

HFD + AMY20, $n=5$ ], or 4-aminopyridine [4-AP, $3 \mathrm{mM}$; diamonds; $\mathrm{ND}, n=5 ; \mathrm{HFD}, n=4 ; \mathrm{HFD}+\mathrm{AMY} 20, n=5])$, or the guanylate cyclase inhibitor $1 \mathrm{H}-[1,2,4]$ oxadiazolo[4,3-a]quinoxalin-1-one (ODQ, $10 \mu \mathrm{M}$; up triangles; ND, $n=4$; HFD, $n=4$; HFD + AMY20, $n=4)$. On the steady-state contraction, sodium nitroprusside (SNP, 1-1000 nM) was added to produce vasorelaxant responses, which were expressed as $\%$ of the control contraction induced by PHE before SNP addition. Values are mean \pm SEM. $* p<0.05$ in comparison with the same concentration in ND group (two-way ANOVA followed by Holm-Sidak test) 


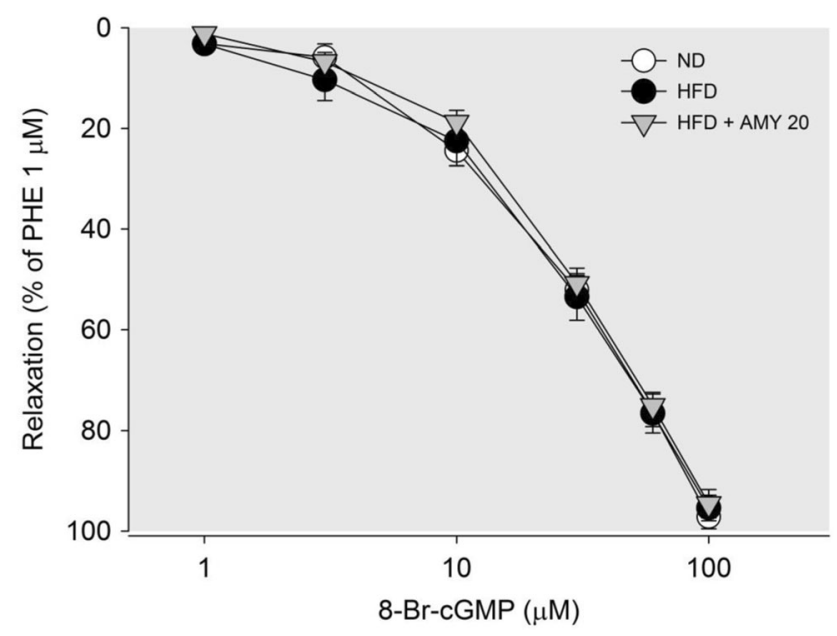

Fig. 5 Vasorelaxant response to 8 -Br-cGMP $(1-100 \mu \mathrm{M})$ in precontracted aortic rings with PHE in mice receiving a ND, HFD, or HFD with alpha, beta amyrin diet. Values are mean and S.E.M. expressed as percent contraction of PHE $(1 \mu \mathrm{M})$. Vertical bars indicate SEM. (ND, $n=7 ; \mathrm{HFD}, n=7 ; \mathrm{HFD}+\mathrm{AMY} 20, n=6)$

$n=7)$ or the HFD + AMY $20 \mathrm{mg} / \mathrm{kg}$ group $\left(\mathrm{pD}_{2}=4.54[4.44\right.$ $4.64] ; n=6)(p>0.05)$.

\section{Discussion}

In this study, mice fed a HFD for 15 weeks showed increased body weights and abdominal fat mass, hyperglycemia, hyperinsulinemia, and hyperlipidemia, characterizing an insulin resistance and obesity state that was significantly abrogated in the group of animals treated with AMY, confirming our earlier findings (Santos et al. 2012; Carvalho et al. 2017). Obesity is a risk factor for cardiovascular disease, and evidence indicates that a high-fat diet induces endothelial dysfunction through the inhibition of nitric oxide (NO) produced by the endothelium (Yang et al. 2007; Magne et al. 2009). Moreover, pro-inflammatory cytokines produced by perivascular fat may also contribute to endothelial dysfunction and smooth muscle cell dysfunction and to the pathogenesis of vascular disease in obese states (Iantorno et al. 2014). Further, hyperlipidemia may alter the vascular response to vasoactive agents (Li et al. 2010). It has been suggested that the obesityassociated vascular dysfunction is, at least in part, reversible with weight-loss strategies (Ziccardi et al. 2002). Since AMY has exhibited anti-inflammatory (Melo et al. 2011) and weight-loss potential in HFD-induced obese mice, we examined AMY for the first time using a vascular reactivity assay in this ex vivo study, using the diet-induced mouse model of obesity.

The reactivity of the aortas isolated from obese and control mice to cumulative concentrations of contractile agents, such as PHE and $\mathrm{KCl}$, was analyzed. In addition, emphasis was given to the changes caused by diet on the endothelium- dependent relaxing properties of $\mathrm{ACh}$ and the endotheliumindependent effects of sodium nitroprusside (SNP). Except for preparations contracted under the depolarizing stimulus induced by $\mathrm{KCl}$, the functional effects induced by PHE, ACh, and SNP were biased at different extents in arteries of obese mice. Indeed, the PHE-induced contractions were significantly decreased in the aortas of mice subjected to a HFD, an observation that is consistent with the studies of Liu et al. (2014), which showed down-regulation of the $\alpha$ adrenoceptor-mediated signaling cascade (with lesser involvement of inositol 1,4,5-trisphosphate and protein kinase C) resulting in decreased $\mathrm{Ca}^{2+}$ influx. Thus, reversal of the attenuated contraction induced by PHE in the obese mice reveals that AMY possesses potential effects to prevent detrimental changes in vascular reactivity, including the endothelial dysfunction associated with obesity.

There is evidence that impairment of NO synthesis represents a central defect that triggers many of the vascular abnormalities characteristic of obesity states (Deng et al. 2010; Martins et al. 2010). The endothelium modulates vascular tone through the release of vasoactive agents, such as NO. The relaxing role exerted by the endothelium was examined in aortic rings submaximally contracted with PHE and stimulated to relax using cumulative concentrations of $\mathrm{ACh}$, which induces relaxation through the endothelium-dependent release of NO involving muscarinic receptor activation (Moncada et al. 1989). The results of the present study have demonstrated that in mice subjected to an experimental HFD regimen, vasorelaxation in response to $\mathrm{ACh}$ was attenuated, a phenomenon also prevented by AMY treatment, which significantly restored the diminished relaxant effects of ACh.

Similarly, the relaxing effects induced by SNP were reduced in the tissues of HFD mice. It is known that the NO donor SNP is largely an endothelium-independent relaxant agent that exerts a direct action on the vascular smooth muscle (Bonaventura et al. 2008). Like ACh, SNP induces relaxation in vascular smooth muscle mainly through a cGMPdependent mechanism (Moncada et al. 1989). Once cGMP is produced as a result of the ACh- or SNP-induced soluble guanylate cyclase stimulation, cGMP targets proteins known as cGMP-dependent protein kinases (e.g., protein kinase G [PKG]; Lucas et al. 2000). Targeted PKG then modulates additional phenomena such as the gating of $\mathrm{K}^{+}$channels, which results in membrane hyperpolarization and smooth muscle relaxation (Kubo et al. 1994). In the present study, the vasorelaxant effects of SNP under a $\mathrm{KCl}$ stimulus were significantly reduced compared to the PHE-induced contractions, likely because the relaxant efficacy of compounds that recruit hyperpolarizing phenomena involving the opening of $\mathrm{K}^{+}$channels, such as SNP, is lost under depolarizing conditions imposed by a high extracellular $(60 \mathrm{mM}) \mathrm{K}^{+}$concentration (Ribeiro-Filho et al. 2012). In addition, the relaxing effects of SNP did not differ between tissues obtained from mice 
subjected to different diet regimens. Thus, it is reasonable to consider that the decreased vasorelaxation to both $\mathrm{ACh}$ and SNP observed in the aortic rings from HFD mice might somehow be a result of an impaired recruitment of $\mathrm{K}^{+}$channels imposed by obesity.

To evaluate such a hypothesis, the aortic rings were incubated with four inhibitors of the $\mathrm{K}^{+}$channel activity in smooth muscle cells: the large-conductance $\mathrm{Ca}^{2+}$-activated potassium channel $\left(\mathrm{BK}_{\mathrm{Ca}}\right)$ blocker TEA (Cook 1989), the smallconductance $\mathrm{Ca}^{2+}$-activated $\mathrm{K}^{+}$channel (SK) blocker apamin (Murphy and Brayden 1995), the $\mathrm{K}_{\mathrm{ATP}}$ channel blocker glibenclamide (Standen et al. 1989), and the voltagedependent $K_{V}$ channel inhibitor 4-AP (Satake et al. 1996). Whereas GLIB did not cause significant changes, TEA, apamin, and 4-AP decreased the relaxation of aortic rings from the ND mice, supporting the involvement of $\mathrm{BK}_{\mathrm{Ca}}$ and $\mathrm{K}_{\mathrm{V}}$, but not $\mathrm{K}_{\mathrm{ATP}}$ channels, as an underlying mechanism involved in the vasorelaxation effects of ACh and SNP in these tissues. In contrast, the vasorelaxant effects of ACh in aortic rings from the HFD mice were not influenced by the presence of 4-AP and apamin, while TEA was almost inert against the vascular response to ACh in the HFD tissues (only a single concentration was significantly decreased in comparison with the ND group). The relaxant response induced by SNP was refractory to the presence of TEA, 4-AP, and apamin. Such findings suggest a decrease in the essential role of $\mathrm{K}^{+}$channels mediating vascular tone in the aortic rings from HFD mice. Inhibited activity of $\mathrm{BK}_{\mathrm{Ca}}$ has been attributed to the augmented vascular resistance in experimental models of obesity. In fact, reduced $\mathrm{BK}_{\mathrm{Ca}}$ current was recorded in coronary artery smooth muscle cells obtained from a swine model of metabolic syndrome (Borbouse et al. 2009). In addition, the vasodilator effects of an adenosine analog were not affected by selective $\mathrm{BK}_{\mathrm{Ca}}$ channel blockade with iberiotoxin in coronary arteries of obese animals, whereas it was reduced in the normal diet control animals (Borbouse et al. 2009). Franke et al. (2004) also reported reduced $\mathrm{K}_{\mathrm{V}}$ channel activity in coronary arteries from HFD-fed pigs.

Aortic rings from HFD mice treated with AMY were susceptible to pharmacological blockade of $\mathrm{K}^{+}$channels, but only TEA was able to decrease the vasorelaxant effects of ACh or SNP. Such findings suggest, at least partially, that AMY preserved the ability of the smooth muscle cells to produce endothelium-dependent and endothelium-independent relaxant responses via guanylate cyclase-elicited recruitment of $\mathrm{Ca}^{2+}$-sensitive $\mathrm{BK}_{\mathrm{Ca}}$, but not $\mathrm{K}_{\mathrm{v}}$ channels. The experiments with apamin preclude the small-conductance $\mathrm{Ca}^{2+}$-activated $\mathrm{K}^{+}$-channel (SK) as a target for the actions induced by AMY. The involvement of guanylate cyclase in the vasorelaxant effects of ACh and SNP was confirmed by the evident inhibition of preparations caused by treatment with the selective inhibitor of guanylate cyclase enzyme, ODQ (Garthwaite et al. 1995). Moreover, the lack of difference significant difference between diet regimens in the vasorelaxant profile on ODQ-treated preparations (data not shown) reinforces the notion that a HFD is somehow able to disrupt the coupling between the guanylate cyclase-derived cGMP production and the subsequent recruitment of target proteins involved in the hyperpolarizing phenomena that ultimately determine the vasorelaxant phenotype in a mouse aorta.

The hypothesis above is reinforced by the results observed with 8-Br-cGMP. In fact, even in the aortic rings of HFD mice, exogenous administration of this stable cGMP analog was able to induce a vasorelaxant effect that did not differ from that observed in the tissues of ND mice, i.e., the aortic smooth muscle cells from the HFD mice maintained the native ability to respond to exogenous cGMP. However, whether cGMP production occurs via guanylate cyclase stimulation, the HFD regimen selectively determined an incomplete vasorelaxant response. Importantly, although the mechanism could not be precisely determined in the present approach, it is noteworthy that AMY impaired such disruption, suggesting a potential therapeutic role of this compound in obesity.

Although the family of $\mathrm{K}^{+}$channels is a main target of the cGMP-dependent protein kinases (PKG), $\mathrm{K}^{+}$channel activity can be modulated directly. Mistry and Garland (1998) showed that $\mathrm{NO}$ and $\mathrm{NO}$ donors can directly stimulate $\mathrm{BK}_{\mathrm{Ca}}$ activity in cells isolated from the rat mesenteric artery, an action that was not affected by soluble guanylate cyclase inhibition. Thus, we hypothesize that the reduced $\mathrm{K}^{+}$channel activity observed in the present model is due to a decrease in NO production or a deficient action of $\mathrm{NO}$, which requires a detailed further study.

In summary, the present study demonstrates that the HFD induces adiposity, increased body weight gain, and impaired vascular reactivity and that these effects could be ameliorated by AMY, a pentacyclic triterpenoid. AMY prevented the HFD-induced weight gain, insulin resistance, dyslipidemia, and endothelial dysfunction, and these results may, in part, contribute to the improvement of the impaired vascular function in aortic rings caused by a HFD, probably by a restoration in $\mathrm{K}^{+}$channel activity.

Acknowledgements This research was supported by the grants and fellowships from Conselho Nacional de Desenvolvimento Científico e Tecnológico (CNPq) and Fundação Cearense de Apoio ao Desenvolvimento Científico e Tecnológico (FUNCAP). We are grateful to Maria Aldiléia Rocha Morais for their excellent technical assistance.

\section{Compliance with ethical standards}

Conflict of interest The authors declare that they have no conflict of interest.

Ethical approval All applicable international, national, and/or institutional guidelines for the care and use of animals were followed. All procedures performed in studies involving animals were in accordance with the ethical standards of the institution (Federal University of Ceará). 


\section{References}

Barton M, Furrer J (2003) Cardiovascular consequences of the obesity pandemic: need for action. Expert Opin Investig Drugs 12:17571759. doi:10.1517/13543784.12.11.1757

Boger RH, Bode-Boger SM, Thiele W, Junker W, Alexander K, Frolich JC (1997) Biochemical evidence for impaired nitric oxide synthesis in patients with peripheral arterial occlusive disease. Circulation 95: 2068-2074. doi:10.1161/01.CIR.95.8.2068

Bonaventura D, Lunardi CN, Rodrigues GJ, Neto MA, Bendhack LM (2008) A novel mechanism of vascular relaxation induced by sodium nitroprusside in the isolated rat aorta. Nitric Oxide 18:287-295. doi:10.1016/j.niox.2008.02.004

Borbouse L, Dick GM, Asano S, Bender SB, Dincer UD, Payne GA, Neeb ZP, Bratz IN, Sturek M, Tune JD (2009) Impaired function of coronary $\mathrm{BK}_{\mathrm{Ca}}$ channels in metabolic syndrome. Am J Physiol Heart Circ Physiol 297:H1629-H1637. doi:10.1152/ajpheart. 00466.2009

Cai J, Zhao L, Zhu E, Guo J (2014) Stimulating effect of a new triterpene derived from Anoectochilus elwesii on glucose uptake in insulinresistant human HepG2 cells. Nat Prod Res 28:2163-2168. doi:10. 1080/14786419.2014.931388

Carvalho KM, Marinho Filho JD, de Melo TS, Araújo AJ, Quetz Jda S, da Cunha MP, de Melo KM, da Silva AA, Tomé AR, Havt A, Fonseca SG, Brito GA, Chaves MH, Rao VS, Santos FA (2015) The resin from Protium heptaphyllum prevents high-fat diet-induced obesity in mice: scientific evidence and potential mechanisms. Evid Based Complement Alternat Med 2015:106157. doi:10.1155/2015/ 106157

Carvalho KM, de Melo TS, de Melo KM, Quinderé AL, de Oliveira FT, Viana AF, Nunes PI, Quetz JD, Viana DA, da Silva AA, Havt A, Fonseca SG, Chaves MH, Rao VS, Santos FA (2017) Amyrins from Protium heptaphyllum reduce high-fat diet-induced obesity in mice via modulation of enzymatic, hormonal and inflammatory responses. Planta Med 83:285-291. doi:10.1055/s-0042-114222

Castellano JM, Guinda A, Delgado T, Rada M, Cayuela JA (2013) Biochemical basis of the antidiabetic activity of oleanolic acid and related pentacyclic triterpenes. Diabetes 62:1791-1799. doi:10. 2337/db12-1215

Cook NS (1989) Effect of some potassium channel blockers on contractile responses of the rabbit aorta. J Cardiovasc Pharmacol 13:299306

Costa RRS, Villela NR, Souza MGC, Boa BCS, Cyrino FZGA, Silva SV, Lisboa PC, Moura EG, Barja-Fidalgo TC, Bouskela E (2011) High fat diet induces central obesity, insulin resistance and microvascular dysfunction in hamsters. Microvasc Res 82:416-422. doi:10.1016/j. mvr.2011.08.007

Deng G, Long Y, Yu YR, Li MR (2010) Adiponectin directly improves endothelial dysfunction in obese rats through the AMPK-eNOS pathway. Int J Obes 34:165-171. doi:10.1038/ijo.2009.205

de Melo CL, Queiroz MG, Arruda Filho AC, Rodrigues AM, de Sousa DF, Almeida JG, Pessoa OD, Silveira ER, Menezes DB, Melo TS, Santos FA, Rao VS (2009) Betulinic acid, a natural pentacyclic triterpenoid, prevents abdominal fat accumulation in mice fed a high-fat diet. J Agric Food Chem 57:8776-8781. doi:10.1021/ jf900768w

de Melo CL, Queiroz MGR, Fonseca SG, Bizerra AM, Lemos TL, Melo TS, Santos FA, Rao VS (2010) Oleanolic acid, a natural triterpenoid improves blood glucose tolerance in normal mice and ameliorates visceral obesity in mice fed a high-fat diet. Chem Biol Interact 185: 59-65. doi:10.1016/j.cbi.2010.02.028

Estadella D, Oyama LM, Dâmaso AR, Ribeiro EB, Oller do Nascimento CM (2004) Effect of palatable hyperlipidic diet on lipid metabolism of sedentary and exercised rats. Nutrition 20:218-224. doi:10.1016/ j.nut.2003.10.008
Franke R, Yang Y, Rubin LJ, Magliola L, Jones AW (2004) High-fat diet alters $\mathrm{K}^{+}$-currents in porcine coronary arteries and adenosine sensitivity during metabolic inhibition. J Cardiovasc Pharmacol 43:495-503 PMID: 15085060

Garthwaite J, Southam E, Boulton CL, Nielsen EB, Schmidt K, Mayer B (1995) Potent and selective inhibition of nitric oxide-sensitive guanylyl cyclase by $1 \mathrm{H}-[1,2,4]$ oxadiazolo[4,3-a]quinoxalin-1-one. Mol Pharmacol 48:184-188 PMID: 7544433

Iantorno M, Campia U, Di Daniele N, Nistico S, Forleo GB, Cardillo C, Tesauro M (2014) Obesity, inflammation and endothelial dysfunction. J Biol Regul Homeost Agents 28:169-176 PMID: 25001649

Kougias P, Chai H, Lin PH, Yao Q, Lumsden AB, Chen C (2005) Effects of adipocyte-derived cytokines on endothelial functions: implication of vascular disease. J Surg Res 126:1211-1229. doi:10.1016/j.jss. 2004.12.023

Kubo M, Nakaya Y, Matsuoka S, Saito K, Kuroda Y (1994) Atrial natriuretic factor and isosorbide dinitrate modulate the gating of ATPsensitive $\mathrm{K}^{+}$channels in cultured vascular smooth muscle cells. Circ Res 74:471-476. doi:10.1161/01.RES.74.3.471

Li R, Xu M, Wang X, Wang Y, Lau WB, Yuan Y, Yi W, Wei X, Lopez BL, Christopher TA (2010) Reduced vascular responsiveness to adiponectin in hyperlipidemic rats-mechanisms and significance. $\mathrm{J}$ Mol Cell Cardiol 49:508-515. doi:10.1016/j.yjmcc.2010.03.002

Liu W, Lin R, Liu A, Du L, Chen Q (2010) Prevalence and association between obesity and metabolic syndrome among Chinese elementary school children: a school-based survey. BMC Public Health 10: 780. doi:10.1186/1471-2458-10-780

Liu L, Liu J, Gao Y, Yu X, Dou D, Huang Y (2014) Protein kinase C $\delta$ contributes to phenylephrine-mediated contraction in the aortae of high fat diet-induced obese mice. Biochem Biophys Res Commun 446:1179-1183. doi:10.1016/j.bbrc.2014.03.065

Lucas KA, Pitari GM, Kazerounian S, Ruiz-Stewart I, Park J, Schulz S, Chepenik KP, Waldman SA (2000) Guanylyl cyclases and signaling by cyclic GMP. Pharmacol Rev 52:375-414 PMID: 10977868

Magne J, Huneau JF, Tsikas D, Delemasure S, Rochette L, Tome D, Mariotti F (2009) Rapeseed protein in a high-fat mixed meal alleviates postprandial systemic and vascular oxidative stress and prevents vascular endothelial dysfunction in healthy rats. J Nutr 139:1660 1666. doi:10.3945/jn.109.107441

Mahato SB, Kundu AP (1994) 13 C NMR spectra of pentacyclic triterpenoids - a compilation and some salient features. Phytochemistry 37:1517-1575

Martins MA, Catta-Preta M, Mandarim-de-Lacerda CA, Aguila MB, Brunini TC, Mendes-Ribeiro AC (2010) High fat diets modulate nitric oxide biosyntesis and antioxidant defense in red blood cells from C57BL/6 mice. Arch Biochem Biophys 499:56-61. doi:10. 1016/j.abb.2010.04.025

Melo CM, Morais TC, Tomé AR, Brito GA, Chaves MH, Rao VS, Santos FA (2011) Anti-inflammatory effect of $\alpha, \beta$-amyrin, a triterpene from Protium heptaphyllum, on cerulean-induced acute pancreatitis in mice. Inflamm Res 60:673-681. doi:10.1007/s00011-011-0321-x

Mistry DK, Garland CJ (1998) Nitric oxide (NO)-induced activation of large conductance $\mathrm{Ca}^{2+}$-dependent $\mathrm{K}^{+}$channels $(\mathrm{BK}(\mathrm{Ca}))$ in smooth muscle cells isolated from the rat mesenteric artery. $\mathrm{Br} \mathrm{J}$ Pharmacol 124:1131-1140. doi:10.1038/sj.bjp.0701940

Moncada S, Palmer RM, Higgs EA (1989) The biological significance of nitric oxide formation from L-arginine. Biochem Soc Trans 17:642 644. doi:10.1042/bst0170642

Mundy AL, Hass E, Bhattacharya I, Widmer CC, Kretz M, HofmannLehmann R, Minotti R, Barton M (2007) Fat intake modifies vascular responsiveness and receptor expression of vasoconstrictors: implications for diet-induced obesity. Cardiovasc Res 73:368-375. doi:10.1016/j.cardiores.2006.11.019

Murphy ME, Brayden JE (1995) Apamin-sensitive $\mathrm{K}^{+}$channels mediate an endothelium-dependent hyperpolarization in rabbit mesenteric arteries. J Physiol 489:723-734 PMID: 8788937 
Nascimento TB, Ferreira Baptista RF, Pereira PC, Campos DHS, Leopoldo AS, Leopoldo APL, Oliveira Júnior SA, Padovani CR, Cicogna AC, Sandra Cordellini S (2011) Vascular alterations in high-fat diet-obese rats: role of endothelial L-arginine/NO pathway. Arq Bras Cardiol 97: 40-45. doi:10.1590/S0066-782X2011005000063

Olea RSG, Roque NF (1990) Análise de misturas de triterpenos por RMN de ${ }^{13} \mathrm{C}$. Quim Nova 13:278-281

Porto NP, Jucá DM, Lahlou S, Coelho-de-Souza AN, Duarte GP, Magalhães PJ (2010) Effects of $\mathrm{K}^{+}$channels inhibitors on the cholinergic relaxation of the isolated aorta of adult offspring rats exposed to maternal diabetes. Exp Clin Endocrinol Diabetes 118:360 363. doi:10.1055/s-0029-1241824

Rao VS, de Melo CL, Queiroz MG, Lemos TL, Menezes DB, Melo TS, Santos FA (2011) Ursolic acid, a pentacyclic triterpene from Sambucus australis, prevents abdominal adiposity in mice fed a high-fat diet. J Med Food 14:1375-1382. doi:10.1089/jmf.2010.0267

Reriani MK, Lerman LO, Lerman A (2010) Endothelial function as a functional expression of cardiovascular risk factors. Biomark Med 4:351-360. doi:10.2217/bmm.10.61

Ribeiro-Filho HV, Brito TS, Lima FJ, Pinho JP, Sousa DF, Silva MT, de Siqueira RJ, Cosker F, Bastos VP, Santos AA, Magalhães PJ (2012) Talking about bioelectrical potentials using rings of the mesenteric artery without glass micropipettes. Adv Physiol Educ 36:336-344. doi:10.1152/advan.00050.2012

Santos FA, Frota JT, Arruda BR, de Melo TS, da Silva AA, Brito GA, Chaves MH, Rao VS (2012) Antihyperglycemic and hypolipidemic effects of $\alpha, \beta$-amyrin, a triterpenoid mixture from Protium heptaphyllum in mice. Lipids Health Dis 11:98. doi:10.1186/1476511X-11-98

Satake N, Shibata M, Shibata S (1996) The inhibitory effects of iberiotoxin and 4-aminopyridine on the relaxation induced by beta1- and beta2-adrenoceptor activation in rat aortic rings. Br J Pharmacol 119:505-510 PMID: 8894170

Shanker J, Rao VS, Ravindran V, Dhanalakshmi B, Hebbagodi S, Kakkar VV (2012) Relationship of adiponectin and leptin to coronary artery disease, classical cardiovascular risk factors and atherothrombotic biomarkers in the IARS cohort. Thromb Haemost 108:769-780. doi:10.1160/TH12-04-0263
Standen NB, Quayle JM, Davies NW, Brayden JE, Huang Y, Nelson MT (1989) Hyperpolarizing vasodilators activate ATP-sensitive $\mathrm{K}^{+}$ channels in arterial smooth muscle. Science 245:177-180. doi:10. 1126/science. 2501869

Sudhahar V, Kumar SA, Varalakshmi P (2006) Role of lupeol and lupeol linoleate on lipemic-oxidative stress in experimental hypercholesterolemia. Life Sci 78:1329-1335 PMID: 16216277

Van de Voorde J, Boydens C, Pauwels B, Decaluwé K (2014) Perivascular adipose tissue, inflammation and vascular dysfunction in obesity. Curr Vasc Pharmacol 12:403-411 PMID: 24846230

Vieira-Junior GM, Souza CML, Chaves MH (2005) Resina de Protium heptaphyllum: isolamento, caracterização estrutural e avaliação das propriedades térmicas. Quím Nova 28:183-187

Virdis A, Neves MF, Duranti E, Bernini G, Taddei S (2013) Microvascular endothelial dysfunction in obesity and hypertension. Curr Pharm Des 19:2382-2389. doi:10.2174/1381612811319130006

Walden R, Tomlinson B (2011) Cardiovascular disease. In: Benzie IFF, Wachtel-Galor S (eds) Herbal medicine: biomolecular and clinical aspects, 2nd edn. CRC Press, Boca Raton, pp 333-359

Wilk G, Osmenda G, Matusik P, Nowakowski D, Jasiewicz-Honkisz B, Ignacak A, Cześnikiewicz-Guzik M, Guzik TJ (2013) Endothelial function assessment in atherosclerosis: comparison of brachial artery flow-mediated vasodilation and peripheral arterial tonometry. Pol Arch Med Wewn 123:443-452 PMID: 24025637

Xiang M, Wang J, Zhang Y, Ling J, Xu X (2012) Attenuation of aortic injury by ursolic acid through RAGE-Nox-NF $\kappa$ B pathway in streptozocin-induced diabetic rats. Arch Pharm Res 35:877-886. doi:10.1007/s12272-012-0513-0

Yang N, Ying C, Xu M, Zuo X, Ye X, Liu L, Nara Y, Sun X (2007) Highfat diet upregulates caveolin-1 expression in aorta of diet-induced obese but not in diet-resistant rats. Cardiovasc Res 76:167-174. doi: 10.1016/j.cardiores.2007.05.028

Ziccardi P, Nappo F, Giugliano G, Esposito K, Marfella R, Cioffi M, D'Andrea F, Molinari AM, Giugliano D (2002) Reduction of inflammatory cytokine concentrations and improvement of endothelial functions in obese women after weight loss over one year. Circulation 105:804-809. doi:10.1161/hc0702.104279 